\title{
DIMENSI TEOLOGI \\ DALAM RITUAL SEDEKAH BUMI MASYARAKAT MADE
}

\author{
Hassan Nugroho \\ Sekolah Tinggi Ilmu Dakwah al-Hadid Surabaya, Indonesia \\ E-mail: hassan.nugroho@gmail.com
}

\begin{abstract}
This study discusses the phenomenon of tradisi sedekah bumi (giving alms to the mother Earth) in the Village of Made, Sambikerep, Surabaya. The tradition of giving alms to the mother Earth-which has been commonly performed by agrarian society (rural people) in Java as a manifestation of thankfulness upon "the Unseen Power" who is regarded as having power to determine successfulness and failure of harvest-has been, in fact, well preserved by the people of Made until the present days. It has been obviously known that the people of Made are no longer an agrarian society; rather they have become a part of a modern urban society of Surabaya. In other words, theological values of tradisi sedekab bumi performed by the people of Made are intended to be compatible with the development of modern social reality. The study, therefore, seeks to scrutinize the practice of tradisi sedekah bumi performed by the people of Made along with its theological dimensions. It is found that the tradition has been passed on generation to generation as a manifestation of gratefulness, an appreciation to the Earth, a means of strengthening brotherhood among the plural community, and a way to gain prosperity and blessing from God.
\end{abstract}

Keywords: Sedekah bumi; theological dimension; tradition; ritual.

\begin{abstract}
Abstrak: Artikel ini membahas fenomena tradisi sedekah bumi di Desa Made, Sambikerep, Surabaya. Tradisi memberi sedekah kepada ibu Bumi-yang telah lazim dilakukan oleh masyarakat agraris (masyarakat pedesaan) di Jawa sebagai manifestasi syukur atas "Kekuatan Tak Terlihat" yang dianggap memiliki kekuatan untuk menentukan keberhasilan dan kegagalan panen. Tradisi ini dilestarikan dengan baik oleh orang-orang dari Made sampai kini. Diketahui bahwa rakyat Made bukan lagi masyarakat agraris; namun mereka telah menjadi bagian dari masyarakat urban modern di Surabaya. Artikel ini berusaha untuk meneliti praktik tradisi sedekah bumi yang dilakukan oleh masyarakat Made bersama dengan dimensi-dimensi teologisnya. Artikel ini menyimpulkan bahwa tradisi tersebut telah diwariskan dari generasi ke generasi sebagai manifestasi dari rasa terima kasih, penghargaan kepada bumi, sarana untuk memperkuat persaudaraan di antara komunitas plural, dan cara untuk mendapatkan kemakmuran dan berkah dari Tuhan.
\end{abstract}

Keywords: Sedekah bumi; dimensi teologis; tradisi; ritual. 


\section{Pendahuluan}

Masyarakat Indonesia secara umum dan Jawa khususnya memiliki tradisi yang sudah dilakukan dari nenek moyang terdahulu, seperti tradisi yang berkaitan dengan peristiwa kelahiran, kematian dan perkawinan, serta berbagai peristiwa lain. Tradisi-tradisi itu secara turun temurun dilestarikan dengan berbagai motivasi dan tujuan yang tidak lepas dari pandangan hidup masyarakat Jawa pada umumnya. Menurut Mulder, masyarakat Jawa memiliki pandangan hidup yang menekankan pada ketenteraman batin, keselarasan, dan keseimbangan. Pandangan hidup ini merupakan bentuk atas sikap menerima terhadap segala peristiwa yang terjadi dengan menempatkan individu di bawah masyarakat serta masyarakat di bawah alam. Individu memiliki tanggung jawab berupa hak dan kewajiban terhadap masyarakat, dan masyarakat mempunyai kewajiban terhadap alam. ${ }^{1}$

Tradisi mencari berkah di suatu tempat yang dianggap bisa mengabulkan berbagai keinginan ternyata masih ditemukan di berbagai wilayah Indonesia dan masyarakat Jawa pada umumnya. Sedekah bumi atau bersih desa juga merupakan suatu ritual budaya peninggalan nenek moyang sejak ratusan tahun lalu. Ritual sedekah bumi ini, umumnya dilakukan oleh masyarakat pertanian sebagai wujud syukur kepada Zat Gaib yang dianggap menguasai pertanian dan menentukan keberhasilan dan kegagalan panen.

Pada masa agama Islam masuk dibawa Walisongo, ternyata sistem ritual budaya sesaji bumi tidak dihilangkan, akan tetapi dipakai sebagai sarana untuk mensyiarkan ajaran Allah tentang iman dan takwa yang dalam bahasa jawa diistilahkan eling lan waspodo (tidak mempersekutukan Allah dan selalu tunduk dan patuh mengerjakan perintah dan menjauhi larangan Allah). Ritual sesaji yang dulunya dipersembahkan untuk alam kemudian diubah namanya menjadi sedekah bumi yang diberikan kepada manusia, khususnya anak yatim dan fakir miskin tanpa membedakan suku, agama, ras, dan golongan. ${ }^{2}$

Berbagai ritual dalam tradisi budaya yang dilaksanakan oleh masyarakat yang beragama Islam, dalam sejarah telah menambah dan memperkokoh eksistensi ajaran Islam di tengah masyarakat Jawa. Meski demikian, budaya atau adat istiadat memiliki kecenderungan

\footnotetext{
${ }^{1}$ Niels Mulder, Kepribadian Jawa dan Pembangunan Nasional (Yogyakarta: Gadjah Mada University Press, 1981), 65.

2 Slamet DS., Upacara Tradisional dalam Kaitan Peristiwa Kepercayaan (t.t.: Depdikbud, 1984), 168.
} 
akan hilang seiring dengan masuknya akulturasi budaya melalui proses modernisasi dan globalisasi, khususnya di daerah-daerah perkotaan. Dalam konteks ini, hal yang menarik adalah tetap lestarinya ritual sedekah bumi di kelurahan Made, kecamatan Sambi Kerep. Kelurahan ini berada di kawasan Surabaya Barat, yang hanya berjarak sekitar 800 meter dari Waterpark Ciputra. Kelurahan ini juga tergolong unik dibandingkan dengan kelurahan lain di Surabaya, di mana banyak bangunan rumah penduduk yang bergaya arsitektur Jawa, namun mengandung sentuhan rumah adat Bali. Oleh karena itu, sampai ada orang yang menyebut kawasan tersebut sebagai kampung Bali di Surabaya.

Masyarakat di kelurahan Made ini tetap mempertahankan tradisi sedekah bumi itu secara turun menurun sebagai wujud mensyukuri nikmat Allah, ${ }^{3}$ dengan diselingi ragam pertunjukan rakyat, kegiatan keagamaan, dan diakhiri dengan pengajian umum demi menjalin kebersamaan antar-warga. Artinya, sedekah bumi yang diadakan masyarakat desa Made mampu menghilangkan sifat-sifat masyarakat kota yang cenderung individualisme dan semangat keberagamaan yang cenderung menurun, sebab tipologi masyarakat perkotaan umumnya memiliki ciri-ciri kurang religius, individualis, dan rasionalis, sehingga interaksi yang terjadi lebih pada faktor kepentingan dan bersifat pribadi.

Sedekah bumi yang diadakan pada tiap tahunnya di kelurahan Made mampu menumbuhkan semangat kerberagamaan sebagai wujud syukur kepada Tuhan atas limpahan rejeki yang diberikan kepada masyarakat serta mampu menumbuhkan rasa gotong-royong atau persaudaraan antar-masyarakat, sehingga hubungan sosial terjalin dengan baik. Dengan kata lain, ritual sedekah bumi memiliki nilai-nilai teologis yang menjadi tujuan sesuai dengan kepercayaan atau agama yang dianut masyarakat setempat. Oleh karena, nilai-nilai teologis yang dibawa dalam tradisi sedekah bumi masyarakat Made modern juga mengalami banyak penyesuaian dengan keadaan aktual, ${ }^{4}$ sehingga

\footnotetext{
${ }^{3}$ Bersyukur atau syukuran merupakan ibadah kepada Allah sebagaimana dijelaskan oleh firman Allah dalam Q.S. Ibrāhīm [14]: 7, "Dan (ingatlah juga), tatkala Tuhanmu memaklumkan: "Sesungguhnya jika kamu bersyukur, pasti Kami akan menambah (nikmat) kepadamu, dan jika kamu mengingkari (nikmat-Ku), maka sesungguhnya azab-Ku sangat pedih."

${ }^{4}$ Dalam konteks ini, menarik untuk memperhatikan pernyataan Nur Said bahwa perlu adanya akomodasi budaya dalam berteologi agar teologi agama-agama yang terbangun tidak berbenturan dengan realitas sosial yang selalu berubah. Nur Said,
} 
memiliki ciri yang khas, maka tulisan ini ingin menggali lebih dalam dimensi-dimensi teologis dalam tradisi sedekah bumi masyarakat modern Made yang hidup di wilayah perkotaan.

\section{Sejarah dan Kondisi Demografis Kelurahan Made}

Kelurahan Made terbentuk dari penyatuan pedukuhan Watulawang, Ngemplak, dan Made. Kelurahan Made berbatasan dengan Kabupaten Gresik. Sekitar dua puluh tahun yang lalu, kampung Made masih terasing dari perkampungan lain di Surabaya, sebab wilayahnya yang berada di pinggiran kota. Terlebih, akses menuju Made saat itu masih berupa jalan tanah atau makadam. ${ }^{5}$ Lebih jauh lagi, Dukut Imam Widodo menceritakan bahwa tempo dulu, Karisidenan Soerabaia terdiri dari District Soerabaja, District Jabakota, District Bawean, dan District Gunung Kendeng. Desa Made dulunya masuk dalam District Gunung Kendeng, kalau sekarang Lakarsantri. ${ }^{6}$

Ada beberapa versi terkait sejarah dan asal usul Kelurahan Made. Menurut Bambang Sugijarto, kampung Made dahulu bernama Tawangsari. Penggunaan nama Made dilakukan untuk menghormati jasa pejuang revolusi I Made Suganda yang pernah tinggal di kawasan rawa-rawa di kawasan tersebut. Oleh warga setempat, I Made Suganda mendapat panggilan akrab Wak Made, dan beragama Hindu. Dia digambarkan sangat mewarnai kehidupan masyarakat di situ, sehingga sejumlah warga memeluk agama Hindu. Rumahnya kemudian difungsikan sebagai punden dan tak pernah sepi dikunjungi warga. Rumah tersebut diberi nama Punden Singojoyo. Di samping itu, Wak Made juga mengajak masyarakat sekitarnya hidup rukun, meski berbeda agama. ${ }^{7}$ Keberadaan I Made Suganda sebagai pejuang revolusi kemerdekaan masih disangsikan oleh beberapa orang. Adapun perjuang revolusi kemerdekaan yang dimaksud adalah Darmo Sugondo. ${ }^{8}$

\footnotetext{
“Teologi Islam Kontekstual-Transformatif”, Jurnal Fikrah, Vol. 1, No. 1 (JanuariJuni, 2013), 93.

5 Dedy H Syahrul, "Kelurahan Made, Kampung Bali di Surabaya Adakan Ritual Bersama, Rukun meski Beda Agama", Jawa Pos, 20 September 2007.

${ }^{6}$ Dukut Imam Widodo, Hikajat Soerabaia Tempo Doeloe, Vol. 2 (Surabaya: Dukut Publishing, 2008), 349.

7 Syahrul, "Kelurahan Made", Jawa Pos, 20 September 2007.

8 Darmo Sugondo pernah dikejar-kejar oleh tentara Belanda karena menentang pemerintah kolonial Belanda. Ia kemudian bersembunyi dalam Punden Singojoyo.
} 
Menurut versi lain, nama Made bukan berasal dari I Made Suganda. Made adalah bahasa Jawa kuno yang berarti "di tengahtengah". Hal tersebut merujuk pada posisi wilayah Made pada waktu pembukaannya pertama kali. Dikisahkan, dahulu daerah Made dan sekitarnya adalah hutan belukar yang dibuka oleh Ingkang Sinubun (seorang yang dijunjung; tidak diketahui namanya) untuk dijadikan tempat tinggal. Oleh karena pohon besar yang disisakan untuk istirahat berada "ditengah-tengah" daerah perdikan, maka daerah tersebut dinamakan Made."

Menurut Mbah Seniman, istilah Made adalah akronim Macan Gedhe (Harimau Besar) atau Macan Alas Gedhe (Harimau dari hutan besar). Dahulu kala, kawasan Made hanya dihuni satu orang yang memiliki peliharaan Macan Gedhe. Orang itu kemudian bertapa dan membuat petilasan, yang kemudian dikenal sengan Singojoyo atau Mbah Singojoyo, sementara harimau peliharaannya bertugas menjaganya. Sampai suatu ketika, hutan di kawasan selatan rusak dan menyebabkan harimau itu pergi. Lama berselang, harimau itu akhirnya kembali ke tempatnya, sehingga disebut Macan Alas Gedhe, dari sini nama Made terbentuk. Mbah Singojoyo itulah yang kemudian dinisbatkan sebagai pendiri kampung Made. ${ }^{10}$

Hasil studi Bayu Dwi Nurwicaksono yang mengeksplorasi nilai budaya dalam tradisi lisan menjelaskan keberadaan cerita rakyat asal mula Desa Made. Dalam cerita tersebut terdapat tokoh utama, yaitu Singojoyo. Latar tempat yang digunakan dalam cerita adalah alas (hutan) Gunung Liwang-Liwung, yang dianggap merupakan cikal bakal Desa Made, dengan latar waktu masa penjajahan Belanda. Singojoyo merupakan tokoh yang babat hutan Gunung LiwangLiwung untuk membuka Desa Made. Punden Singojoyo merupakan petilasan Mbah Joyo sebelum akhirnya menghilang secara misteirus. ${ }^{11}$

Konon, Darmo Sugondo saat itu selamat dari kejaran tantara Belanda karena diselamatkan oleh Ida Made secara gaib. Lihat http://ayokesurabaya.com, "Kampung Made Balinya Surabaya", Diakses 8 Juni 2016; Dokumen Mbah Seniman, "Sejarah Singkat Desa Made Mengenai Tokoh Pejuang 45 dan Bangunan Punden".

${ }^{9}$ http:/ / desomade.blogspot.co.id, "Histori Made”, Diakses 20 Juni 2016.

${ }^{10}$ Seniman, Wawancara, 20 Juni 2016.

11 Bayu Dwi Nurwicaksono, "Eksplorasi Nilai Budaya dan Pendidikan Karakter Berbasis Kearifan Lokal dalam Tradisi Lisan Rupa Bumi dan Ancangan Revitalisasinya Melalui Implementasi Kurikulum 2013 dan Program Agrowisata” (Tesis--Universitas Pendidikan Indonesia, 2013). 
Dari cerita rakyat itu setidaknya menggambarkan cara pandang dan kepercayaan masyarakat Made terhadap asal-usul wilayahnya. Cerita rakyat dan kepercayaan tersebut merupakan mitos, dan punden Singojoyo sebagai pusat dari cerita tersebut adalah tempat yang sakral. Seperti dijelaskan oleh Kuntowijoyo, bahwa orang Jawa (tradisional) tunduk pada alam, mereka melihat alam sebagai kenyataan yang serba dahsyat, tak terjangkau, dan menguasai manusia. Oleh sebab itu kebudayaan Jawa penuh dengan mitologisasi, sakralisasi, dan mistifikasi. $^{12}$

Secara geografis, Kelurahan Made terletak di Kecamatan Sambikerep, termasuk wilayah Surabaya Barat, dengan ketinggian \pm 12 meter di atas permukaan laut. Luas wilayah Kelurahan Made adalah 4,47 $\mathrm{Km}^{2}$ dengan jarak ke kecamatan $\pm 2 \mathrm{Km}^{13}$ Adapun batas-batas administratif Kelurahan Made adalah sebagai berikut: sebelah utara berbatasan dengan Kelurahan Bringin Kecamatan Sambikerep; sebelah selatan berbatasan dengan Kecamatan Lakarsantri; sebelah timur berbatasan dengan Kelurahan Sambikerep, Kecamatan Sambikerep; dan sebelah barat berbatasan dengan Kabupaten Gresik.

Kelurahan Made sendiri berdekatan dengan kawasan elit Surabaya, yaitu perumahan Citraland. Selain terdapat perumahan mewah dengan jalan dan taman yang rindang, juga terdapat berbagai pertokoan, perkantoran, sarana hiburan Ciputra Waterpark, rumah sakit, sekolah, mulai dari tingkat dasar sampai dengan perguruan tinggi, yaitu Universitas Ciputra, sehingga secara sosiologis terdapat pemandangan yang cukup mencolok di Kelurahan Made, di satu sisi terdapat kawasan perumahan elit dengan berbagai sarana dan prasarananya, di sisi lain terdapat suasana perkampungan.

Secara administratif internal, Kelurahan Made terbagi dalam 8 Rukun Warga (RW) dengan 29 Rukun Tetangga (RT). Berdasarkan data di Kecamatan Sambikerep tahun 2015, jumlah penduduk Kelurahan Made adalah 8158 dengan kepadatan penduduk 1825 Jiwa/ $\mathrm{Km}^{2}$, dengan jenis kelamin laki-laki sejumlah 4289 dan perempuan sejumlah 3288. ${ }^{14}$ Mayoritas penduduk Made adalah suku Jawa, sebagian kecil adalah suku Madura. Mbah Seniman dan

12 Kuntowijoyo, Esai-esai Budaya dan Politik: Selamat Tinggal Mitos Selamat Datang Realitas (Bandung: Mizan, 2002), 108.

13 BPS Kota Surabaya, Kecamatan Sambikerep dalam Angka tahun 2016 (Surabaya: BPS Kota Surabaya, 2016), 1-2.

14 Ibid., 16-18. 
keluarganya merupakan suku Madura yang sudah turun temurun tinggal di kampung Made. ${ }^{15}$

Secara ekonomi, masyarakat Made adalah kelas menengah ke bawah. Data dari BPS Kota Surabaya menunjukkan bahwa jumlah keluarga Pra Sejahtera di Kelurahan Made adalah 110, dan Keluarga Sejahtera Tingkat I adalah $172 .{ }^{16}$ Dari total 1885 keluarga, terdapat 196 kepala keluarga di Kelurahan made yang tidak bekerja, dan 167 kepala keluarga perempuan. ${ }^{17}$

Aktivitas perekonomian penduduk Made, sebagian besar adalah pekerja, banyak di antaranya bekerja di PT. Citraland, termasuk Sadi, putra dari Mbah Seniman. ${ }^{18}$ Ada juga yang berprofesi sebagai petani, peternak, pedagang, dan lain-lain. Mbah Seniman menuturkan bahwa sekitar tahun 1970-an wilayah Made masih didominasi persawahan. Namun ketika pengembang masuk untuk membeli lahan warga dan melakukan pembangunan dengan menggunakan jasa tenaga warga Made, mereka yang semula bertani, karena tidak ada lahan dan adanya kebutuhan tenaga pembangunan, kemudian beralih profesi menjadi tukang bangunan. Ketika ada proyek perluasan kota Surabaya di tahun 1990-an, Kelurahan Made semakin kelihatan maju. Di tahun 2000-an, Kelurahan Made sudah bukan sebuah desa yang terpencil, tetapi bertransformasi menjadi bagian dari Kota Surabaya. ${ }^{19}$

Saat ini aktivitas pertanian di Kelurahan Made memang masih ada, tetapi sistemnya adalah sawah tadah hujan, dengan luas lahan kurang lebih 211,85 Ha. Meski demikian, sebagian besar lahan tersebut bukan milik warga, tetapi lahan milik pengembang yang dimanfaatkan sebagai pertanian. Di Kelurahan Made juga terdapat Gabungan Kelompok Tani Made Bersinar (Gapoktan Made Bersinar) yang beranggotakan sekitar 563 penduduk Kelurahan Made dan melaksanakan kegiatan pertanian di lahan persawahan maupun lahan pekarangan. Tanaman yang dikembangkan oleh Gapoktan Made Bersinar adalah tanaman holtikultura seperti cabe, tomat, jagung, dan tanaman sayuran lainnya.

Pemerintah Kota Surabaya sejak tahun 2009 juga berupaya menerapkan urban farming di Kelurahan Made. Hal tersebut dilakukan untuk meningkatkan perekonomian warga dan memanfaatkan lahan-

\footnotetext{
${ }^{15}$ Seniman, Wawancara, 20 Juni 2016.

${ }^{16}$ BPS Kota Surabaya, Kecamatan Sambikerep, 54.

${ }^{17}$ Ibid., 55-56.

${ }^{18}$ Sadi bin Seniman, Wawancara, 21 Juni 2016.

${ }^{19}$ Saniman, Wawancara, 20 Juni 2016.
} 
lahan yang belum difungsikan, meskipun jumlahnya terbatas. Menurut Kepala Dinas Pertanian Kota Surabaya tahun 2010, Syamsul Arifin, kegiatan ini mampu menarik perhatian dan antusias warga. Warga bahu membahu mulai dari pembelian bibit, mananam hingga pada tahap pemasaran, karena banyak dampak positif yang dapat dirasakan warga seperti meningkatnya penghasilan dan hasil kebun juga makin beragam. Beberapa komoditi pertanian produksi tanaman hortikultura yang disiapkan untuk masyarakat, antara lain pare hijau, pare welut, kacang panjang, gambas, lodrong, terong, sawi cabut, kangkung cabut, bayam cabut, tomat, daun seruni/kenikir, kemangi, daun ketela pohon, terong lalap, krai, mentimun, ketela pohon, jagung sayur, ubi jalar dan cabai merah. ${ }^{20}$

\section{Keragaman Agama dan Kerukunan Masyarakat Made}

Mayoritas warga Kelurahan Made memeluk agama Islam. Hanya tujuh keluarga yang menganut agama Hindu. Menurut Samsari, warga yang rumahnya tak jauh dari Punden Singojoyo sering menggunakan Punden Singojoyo untuk doa bersama, khususnya malam Jumat Kliwon dengan ritual campuran agama Hindu dan Islam, di mana doa-doa yang dipanjatkan adalah doa tahlilan, sedangkan perlengkapan doanya mirip yang biasa disiapkan umat Hindu untuk sesaji, seperti membawa sesajen, dupa, bunga pancawarna, dan macam-macam makanan. ${ }^{21}$

Melihat corak keagamaan masyarakat Kelurahan Made, sekalipun mayoritas Islam, namun praktik-praktik keagamaan yang dijalankan masih kental dengan nuansa sinkretis. Mengacu pada pembagian sub kultural agama Jawa oleh Geertz, ${ }^{22}$ dapat diidentifikasi sebagian masyarakat Made adalah Islam Abangan. Sistem keagamaan tersebut merupakan integrasi yang berimbang antara unsur-unsur animisme sebagai warisan leluhur atau nenek moyang orang Jawa, pengaruh Hindhu, dan pengaruh Islam, yaitu sebuah sinkretisme dasar orang Jawa yang merupakan tradisi sebenarnya masyarakat Jawa. ${ }^{23}$ Mereka tetap tidak meninggalkan kepercayaan terhadap arwah leluhur, para nabi, para malaikat, dan waliyullah yang dipandang memiliki kekuatan

\footnotetext{
${ }^{20}$ http://www.surabaya.go.id, "Antusias Warga di Panen Raya Kelurahan Made", Diakses 13 Maret 2016.

${ }^{21}$ Syahrul, "Kelurahan Made", Harian Jawa Pos, 20 September 2007.

22 Clifford Geertz, Agama Jawa: Abangan, Santri, Priyayi dalam Kebudayaan Jawa, terj. Aswab Mahasin (Jakarta: Pustaka Jaya, 1985).

${ }^{23}$ Ibid., xxx.
} 
magis dan mampu menjadi penyelamat dan perantara doa kepada Allah. Meskipun terdapat kelompok masyarakat Muslim Kelurahan Made yang lebih taat dan dekat dengan praktik kultural kelompok santri, tetapi hal tersebut tidak dominan. Hal tersebut sebagai imbas dari perkembangan wilayah Made dan interaksi dengan kultur perkotaan yang membawa pada kemajuan ilmu pengetahuan dan teknologi serta pemurnian ajaran Islam dari berbagai kelompok keagamaan yang tumbuh di Kota Surabaya.

Ciri utama lainnya yang juga terdapat dalam masyarakat Made adalah tradisi slametan atau kenduren, yang menjadi pusat seluruh sistem keagamaan orang Jawa. Slametan hampir dapat digunakan untuk merespons keseluruhan dinamika hidup, seperti kelahiran, kematian, pernikahan, pindah rumah, mimpi buruk, ganti nama, panen raya, kesembuhan dari sakit, dan sebagainya. ${ }^{24}$ Praktik Sedekah Bumi juga merupakan salah satu bentuk ritual slametan atas keberhasilan panen warga Made, sebagai sebuah tradisi yang terus dipertahankan hingga kini, sekalipun pertanian tidak lagi menjadi mata pencaharian kebanyakan warga Made.

Di tengah keragaman agama dan praktik kultural keagamaan masyarakat Made, sikap tolerasni dan kerjasama terjada di Kelurahan Made, sehingga kehidupan masyarakat dapat berjalan rukun dan harmonis. Mbah Seniman menuturkan bahwa kerukunan umat beragama di Kelurahan Made selama ini berjalan apa adanya dan tidak pernah timbul perselisihan antarumat. Masyarakat Made yang mayoritas Muslim sangat toleran terhadap warga lain yang menganut agama Hindu. Bahkan, sering antara umat Muslim dan Hindhu mengadakan pertemuan bersama. Dia sendiri dulunya merupakan penganut agama Islam. Pada tahun 1981, ayahnya yang bernama Seno Seniman berpindah ke agama Hindu. Dari situ Mbah Seniman dan anggota keluarganya mengikuti jejak orang tuanya, menganut Hindu. ${ }^{25}$ Meski demikian, ada salah satu puteranya yang memeluk agama Islam, dan Mbah Seniman tidak pernah mempermasalahkan hal itu. ${ }^{26}$

\section{Asal Mula dan Perkembangan Tradisi Sedekah Bumi}

Berdasarkan penuturan Mbah Seniman, selaku sesepuh dan Ketua Adat Kampung Made, tradisi sedekah bumi masyarakat Made telah

\footnotetext{
24 Ibid., 3.

25 Syahrul, "Kelurahan Made", Jawa Pos, 20 September 2007.

${ }^{26}$ Sadi bin Seniman, Wawancara, 21 Juni 2016.
} 
berlangsung lama, turun temurun dari nenek moyang masyarakat Made. Mbah Seniman yang lahir tahun 1933 menceritakan bahwa sejak masa kecilnya telah mengikuti tradisi ritual sedekah bumi yang diadakan masyarakat Made. ${ }^{28}$ Tradisi sedekah bumi ini untuk mendoakan agar desa aman, tentram, dan ini adalah sejarah. ${ }^{29}$ Artinya sebagai sebuah warisan sejarah, tradisi sedekah bumi masyarakat Made tidak boleh dilupakan apalagi sampai dihilangkan.

Sebagai sebuah tradisi, ritual sedekah bumi tidak lepas dari musyawarah persetujuan warga, di mana besar kecilnya upacara adat untuk sedekah bumi yang dilaksanakan menurut keadaan hasil panen. Apabila hasil bumi dirasakan baik dan melimpah, maka upacara adat sedekah bumi dimeriahkan dengan gending-gending, giro taloen, srunenan, iling-iling, tari remo, serta jula-juli; tumpengan ikan ayam panggang; kesenian okol (permainan gulat model anak desa); pagelaran wayang kulit atau ludruk. Namun, ketika hasil bumi menurun, upacara adat untuk sedekah bumi tetap dilaksanakan secara sederhana dengan tumpengan saja, tanpa pagelaran kesenian. ${ }^{30}$

Menurut Ketua Peguyuban Sosial Kelurahan Made, Muhammad Nasyik Fahmi, ritual sedekah bumi merupakan bagian dari budaya yang berkembang dalam masyarakat Made. Tradisi tersebut sebenarnya dilakukan sejak zaman nenek moyang. Dia tak memungkiri bahwa tradisi itu mirip prosesi ritual ajaran dalam Hindu. Lebih lanjut, Fahmi menceritakan bahwa ritual tersebut pernah terhenti pada 2001. Namun, selang tiga tahun, ketika terjadi bencana alam tsunami di Aceh, tradisi itu dilanjutkan, tujuannya adalah untuk memohon keselamatan kepada Allah. ${ }^{31}$

Slametan yang menjadi ritual inti masyarakat Jawa bersumber dari kepercayaan adanya makhluk-makhluk halus yang bisa mengganggu manusia. ${ }^{32}$ Ketika agama Hindu-Budha dan Islam masuk ke Jawa, tradisi slametan tetap dipertahankan dengan berbagai modifikasi atau sinkretis dengan praktek keagamaan yang mempengaruhinya. Sebagai contoh dalam hal doa, kerap kali orang Islam Jawa (abangan) yang melakukan slametan menggunakan doa-doa berbahasa Arab atau membaca bacaan berbahasa Arab, seperti pembacaan surah Yāsīn, tahlil, dan sejenisnya. Oleh karena itu, wajar pula jika masyarakat

\footnotetext{
${ }^{28}$ Seniman, Wawancara, 20 Juni 2016.

${ }^{29}$ Ibid.

30 http:/ / desomade.blogspot.co.id, "Histori Made”, Diakses 20 Juni 2016.

31 Syahrul, "Kelurahan Made", Jawa Pos, 20 September 2007.

32 Geertz, Agama Jawa, 7.
} 
Kelurahan Made pada hari ini yang merupakan sub kultur masyarakat Jawa dengan corak kultur abangan percaya bahwa sedekah bumi adalah warisan nenek moyangnya.

Di Jawa, sedekah bumi umum dilakukan di masyarakat agraris untuk mensyukuri hasil pertanian yang didapatkan. Upacara sedekah bumi dipersembahkan kepada penguasa pertanian, Dewi Sri. Akibat pengaruh Islam, tradisi tersebut tetap dilakukan, hanya motifnya bukan lagi dipersembahkan kepada Dewi Sri, tetapi sebagai wujud rasa syukur kepada Allah. Namun demikian, yang menjadi ciri khas di masyarakat Kelurahan Made adalah prosesi sedekah bumi dikaitkan dengan rasa terimakasih atau syukur kepada Mbah Singojoyo yang dianggap sebagai pendiri Kampung Made. Indikasinya adalah kegiatan sedekah bumi selalu di dilaksanakan di Punden Singojoyo, yang dianggap sebagai makam dan petilasan Mbah Singojoyo. Dengan kata lain, sekalipun masyarakat Made modern hari ini telah kehilangan sebagaian besar lahan pertanian karena telah berubah menjadi perumahan, sedekah bumi tetap dilakukan dalam rangka mengucap syukur dan mohon keselamatan kepada Mbah Singojoyo sebagai sosok yang dianggap memiliki kekuatan magis di Kampung Made.

Masyarakat Made sebagaimana masyarakat Jawa pada umumnya juga percaya terhadap keberadaan makhluk halus, baik itu berupa memedi (makhluk halus yang menakut-nakuti), lelembut (makhluk halus yang menyebabkan kesurupan), tuyul (makhluk halus yang karib), demit (makhluk halus yang menghuni suatu tempat), dan danyang (makhluk halus pelindung). ${ }^{33}$ Mbah Singojoyo yang telah meninggal, arwahnya dipercaya tetap ada dan menjadi pelindung masyarakat Made, sehingga dapat dikategorikan sebagai danyang. ${ }^{34}$ Dengan demikian, terdapat proses pengkeramatan dan mitologisasi terhadap tokoh Mbah Singojoyo dengan pundennya, salah satunya adalah dengan melakukan ritual sedekah bumi sebagai bentuk slametan yang dipersembahkan untuk danyang Mbah Singojoyo. Oleh karena itu, tidak berlebihan jika Mbah Seniman selalu menyebut bahwa acara sedekah bumi adalah hari rayanya masyarkat Made, bahkan lebih meriah daripada hari raya Idul Fitri.

\footnotetext{
33 Ibid., 9-23.

34 Geertz menjelaskan bahwa beberapa danyang memang dianggap arwah dari tokoh-tokoh sejarah yang sudah meninggal seperti pendiri desa atau orang yang pertama kali membabat lahan untuk desa. Danyang menetap di suatu tempat yang disebut punden dan merespons permintaan tolong warga yang membutuhkan dengan imbalan menerima janji akan slametan. Ibid., 23-24.
} 
Sejak tahun 2009, tradisi sedekah bumi mendapatkan dukungan penuh dari Pemerintah Kota Surabaya melalui Dinas Kebudayaan dan Pariwisata (Disbudpar). Pada tahun 2011, dalam rangka mengenalkan tradisi sedekah bumi dan menjadi daya tarik wisata kultural Surabaya, Disbudpar menggelar serangkaian acara sedekah bumi masyarakat Made di Taman Bungkul. Kepala Bidang Rekreasi dan Hiburan Umum Disbudpar Kota Surabaya, Agus Purnomo, mengatakan bahwa dengan adanya kegiatan budaya di Taman Bungkul tersebut tentunya diharapkan bisa menarik wisatawan domestik dan mancanegara. Pihaknya akan memperlihatkan ritual ini, mulai dari potong tumpeng hingga acara lokal, seperti kesenian okol.

Hal lain diungkapkan oleh Direktur Surabaya Heritage, Fredy $\mathrm{H}$ Istanto. Fredy, bahwa penampilan atraksi sedekah bumi warga Kelurahan Made di Taman Bungkul tidak ada gregetnya dan kehilangan atmosfer ritual sedekah buminya. Oleh karenanya, dalam penyelenggaraan selanjutnya sedekah bumi masyarakat Made diselenggarakan di Kampung Made yang dipusatkan di Punden Singojoyo. Hal tersebut sangat penting, sebab dengan dilaksanakan di tempat asalnya atau di perkampungan nuansa yang didapatkan lebih asli dan bisa dijual. Sementara kalau dipindah ke tempat netral, konteksnya bisa tidak kena. ${ }^{35}$

\section{Tata Cara dan Makna Sedekah Bumi Masyarakat Made}

Upacara sedekah bumi Masyarakat Made dipusatkan di Punden Singojoyo yang bertempat di Gg. Made Njeroe yang berjarak \pm 300 meter dari Pendopo Agung (Balai Kelurahan). Kegiatan sedekah bumi ini diawali dengan rapat akbar seluruh penduduk dari berbagai kalangan untuk membahas waktu ruwat bumi, termasuk elemen dari pemerintah, tokoh agama, dan perwakilan tiap keluarga. ${ }^{36}$

Mbah Seniman menjelaskan bahwa yang pokok dalam acara sedekah bumi adalah nasi tumpeng raksasa yang dibuat bersama. Ada yang menyiapkan nasi, sayur-mayur, lauk-pauk, dan berbagai hal lainnya. Ritual yang diadakan sehari semalam tersebut juga menampilkan hiburan seperti ludruk serta wayang kulit. Cerita yang diangkat dalam wayang kulit adalah cerita yang bertema kekuasaan Tuhan Yang Maha Esa. Upacara ditutup dengan doa bersama yang

\footnotetext{
35 http://www.surabaya.go.id, “Antusias Warga di Panen Raya Kelurahan Made”, Diakses 13 Juli 2016.

36 http:/ / desomade.blogspot.co.id, “Histori Made”, Diakses 20 Juni 2016.
} 
dipimpin tokoh-tokoh agama, baik dari agama Hindu maupun Islam, untuk keselamatan dan keamanan bagi masyarakat Made. ${ }^{37}$ Ratusan tumpeng yang terkumpul setelah dibacakan doa kemudian dibagikan lagi beramai-ramai kepada masyarakat. ${ }^{38}$

Kegiatan sedekah bumi juga diramaikan dengan lomba menghias aneka hasil bumi, kemudian dikirab keliling kampung. Dalam kegiatan tersebut, Mbah Seniman, selaku sesepuh kampung Made akan menjelaskan sejarah serta pesan-pesan moral ritual sedekah bumi kepada generasi penerus di kampung Made. Ia selalu berpesan agar anak-anak muda dapat meneruskan budaya masyarakat yang sudah turun temurun ini dengan baik. Setelah acara "rebutan" hasil bumi, dilanjutkan dengan pagelaran budaya kuda lumping dan reog, siang hari dilanjutkan dengan "gulat tradisional" yang disebut okol, serta pagelaran wayang kulit. ${ }^{39}$

Okol sebagai tradisional khas masyarakat Made berbeda dengan acara gulat bebas. Di dalam okol ada teknik khusus membanting, sehingga belum tentu yang memiliki tubuh lebih besar menjadi pemenang. Peserta dinyatakan kalah apabila sudah jatuh terpelanting ke tanah. Sementara aturannya adalah harus membuka baju (kecuali perempuan), tidak boleh memukul, menggigit, meninju lawan, serta diharuskan membuka semua asesoris seperti cincin, gelang, dan lainlain. ${ }^{40}$ Tradisi ini bermula ketika waktu itu kemarau panjang terjadi di Made. Di saat air hujan yang sejak lama ditunggu-tunggu oleh warga Made dan sekitarnya turun membasahi bumi, anak-anak desa mengadakan dolanan adu kekuatan yang dinamakan okol. Sementara itu para orang tua mereka tidak pernah melarang dengan adanya permainan tersebut, bahkan untuk melestarikan dolanan okol ini diberikan wadah bersamaan dengan acara ritual sedekah bumi sampai dengan hari ini. ${ }^{41}$

Mbah Seniman menuturkan bahwa dalam sedekah bumi masyarakat Made, hal yang pasti harus ada dan tidak bisa dirubah adalah tumpeng atau gunungan. Sementara kegiatan lain seperti kesenian wayang kulit, okol, tayub, ludruk, dan sebagainya hanyalah tambahan saja. Artinya kegiatan-kegiatan tersebut tidak harus ada dalam ritual

\footnotetext{
${ }^{37}$ Ibid.

${ }^{38}$ Ibid.

39 http://ayokesurabaya.com, "Kampung Made Balinya Surabaya", Diakses 8 Juni 2016.

40“'Adu Okol di Sedekah Bumi”, Jawa Pos, 31 Oktober 2016.

${ }^{41}$ http://desomade.blogspot.co.id, "Histori Made”, Diakses 20 Juni 2016.
} 
sedekah bumi masyarakat Made dan hanya bersifat untuk menyemarakkan serangkaian acara sedekah bumi masyarakat Made. ${ }^{42}$ Tumpeng dibuat dari nasi lengkap dengan berbagai lauk pauk, sayur mayur dan lainnya yang ditata menyerupai bentuk gunung, oleh karenanya disebut pula gunungan. Gunungan dalam bentuk lain juga bisa berupa berbagai hasil bumi mulai dari jenis sayur mayur seperti terong, kacang panjang, tomat, wortel, kubis, dan lain-lain, juga jenis buah-buahan seperti pisang, jeruk, mangga, apel, dan lain-lain. Lebih lanjut Mbah Seniman mengatakan bahwa tumpeng dibentuk seperti gunung, karena gunung adalah simbol kehidupan, simbol bumi, yang merupakan kebutuhan manusia." 43 Hal ini sejalan dengan latar belakang dan tujuan sedekah bumi Masyarakat Made di atas, yaitu selain untuk mohon pertolongan dan keselamatan bagi warga Made, juga untuk mengingatkan masyarakat untuk menjaga bumi/alam, karena bumi/alam adalah kebutuhan manusia.

Tumpeng yang isi pokoknya adalah nasi, juga harus didampingi ayam yang telah disembelih. Mbah Seniman menyatakan, "Potong ayam adalah simbol agar warga Made membuang sifat-sifat seperti ayam yang ada pada dirinya, sehingga bisa tercipta kehidupan yang harmonis di masyarakat Made. Di antara sifat ayam adalah selalu bertengkar ketika dikumpulkan; sifat ini yang dipotong. Jangan sampai manusia meniru sifat ayam. Ketika manusia dikumpulkan harus aman, kalau sampai bertengkar atau konflik berarti keliru." ${ }^{44}$ Hal ini juga sejalan dengan tujuan sedekah bumi, di mana salah satunya adalah untuk membangun persaudaraan dan kerukunan warga Made.

Dalam penentuan waktu sedekah bumi, Mbah Saniman menuturkan bahwa tiap tahunnya tidak ada waktu khusus pelaksanaan sedekah bumi, semuanya tergantung hasil musyawarah warga, termasuk dengan pihak pemerintah. Tetapi umumnya kegiatan sedekah bumi dilaksanakan dua atau tiga bulan setelah Hari Raya Idul Fitri. ${ }^{45}$ Dulu memang sedekah bumi dilaksanakan setelah musim panen padi, karena orientasinya juga untuk mensyukuri keberhasilan panen. Namun saat ini, karena pertanian tidak lagi dominan di masyarakat Made, maka tidak mungkin mengikuti siklus tersebut,

\footnotetext{
${ }^{42}$ Seniman, Wawancara, 20 Juni 2016.

43 Ibid.

${ }^{44}$ Ibid.

${ }^{45}$ Ibid.
} 
sehingga penetapan waktunya dilaksanakan melalui musywarah warga, dengan panduan waktu setelah Hari Raya Idul Fitri.

\section{Dimensi Teologis Ritual Sedekah Bumi Masyarakat Made}

Dalam konteks masyarakat Made yang sudah modern dan tidak lagi bercorak agraris, karena pertanian tidak lagi menjadi mayoritas mata pencaharian warganya, tradisi sedekah bumi tetap dilaksanakan dengan berbagai penyesuaian-penyesuaiannya. Terlebih pemerintah turut pula untuk menghidupkan kegiatan sedekah bumi dengan semarak sebagai aset yang bisa dijual dan mendatangkan wisatawan ke Surabaya. Walhasil, tradisi sedekah bumi masyarakat Made modern tidak hanya terdapat nuansa ritual tetapi sekaligus pawai budaya yang semarak. Sungguhpun demikian terdapat prosesi-prosesi inti yang harus ada dalam pelaksanaan sedekah bumi masyarakat Made sebagai satu ciri dan prasyarat pelaksanaan ritual sedekah bumi. Perpaduan ritus tradisional dan komodifikasi pagelaran dalam sedekah bumi masyarakat Made menjadikannya sesuatu yang khas dan unik, sebab tradisi bertemu dengan modernitas. Meski demikian, masyarakat Made mampu mempertahankan nilai-nilai inti dalam ritual sedekah bumi, sekalipun masyarakat secara umum dan pemerintah lebih melihatnya sebagai upaya mempertahankan dan melestarikan budaya sebagai warisan nenek moyang.

Nilai-nilai teologis yang dibawa dalam tradisi sedekah bumi masyarakat Made modern juga mengalami penyesuaian-penyesuaian dengan keadaan aktual dan berbagai paduan dalam acara sedekah bumi. Untuk memahami dimensi-dimensi teologis dalam tradisi sedekah bumi masyarakat Made dapat mengacu pada tujuan kegiatan sedekah bumi, sebab dalam tujuan tersebut mengandung nilai-nilai yang hendak dihidupkan dan dilestarikan oleh sesepuh masyarakat Made, yang dipandang sejalan dengan konteks masyarakat Made modern. Tujuan sedekah bumi masyarakat Made, terkait tiga hal: a) memohon keselamatan kepada Tuhan Yang Maha Esa dan atau arwah leluhur (Mbah Singojoyo); b) menghargai bumi (alam) sebagai sumber kehidupan; dan c) membangun persaudaraan dan kerukunan antarmanusia.

\section{Dimensi Kepercayaan terbadap Zat Yang Gaib}

Setiap konstruk gagasan teologi selalu memiliki dimensi utama kepada kepercayaan terhadap Zat yang transenden, sebab pokok 
teologi adalah ilmu atau gagasan terkait Tuhan. Dalam Dictionary of Philosophy and Religion, William L. Reese menjelaskan bahwa teologi merupakan diskursus atau pemikiran tentang Tuhan (discourse or reason concerning God). ${ }^{46}$ Teologi dapat pula dimaknai sebagai konsep berpikir dan bertindak yang dihubungkan dengan "Yang Gaib" yang menciptakan sekaligus mengatur manusia dan alam. ${ }^{47}$ Oleh karenanya, konsep teologi senantiasa menjadi dasar dalam sebuah agama atau kepercayaan tertentu. Varian pemikiran atau diskursus tentang Ketuhanan inilah yang menjadikan varian agama, kepercayaan, bahkan sekte-sekte dalam sebuah agama atau kepercayaan. Ketika sebuah pemikiran teologi dikonstrusi sedemikian rupa dalam konteks masyarakat modern, gagasan kepercayaan terhadap Tuhan atau Zat Pencipta dan Penguasa tetap menjadi pusat pemikiran teologis tersebut.

Ritual sedekah bumi merupakan tradisi masyaratkat Jawa yang telah dilakukan secara turun temurun sebagai bentuk rasa syukur atas nikmat yang diberikan dari hasil bercocok tanam. Sedekah bumi juga merupakan salah satu bentuk slametan, yang menjadi pokok ritual dalam masyarakat Jawa. Dalam bentuk originalnya, rasa syukur pada ritual sedekah bumi ditujukan kepada Zat Gaib yang dianggap menguasai pertanian atau sebagai penentu keberhasilan dan kegagalan mereka dalam bercocok tanam. Zat Gaib tersebut mulanya dianggap merupakan roh atau kekuatan yang memiliki alam (pertanian). Dalam perkembangnya, Zat Gaib tersebut dipesonifikasikan sebagai Dewi Sri, yang melambangkan kesuburan, dan dipercaya memiliki kekuatan untuk menentukan keberhasilan pertanian. Ketika Islam masuk, Zat Gaib yang diperkenalkan kepada masyarakat Jawa adalah Allah sebagai Tuhan Pencipta, Penguasa dan Penentu keberhasilan dalam pertanian. Dalam bentuk lainnya, sedekah bumi juga ditujukan kepada arwah leluhur, khususnya pendiri desa. Arwah mereka dianggap masih hidup dan memiliki kekuatan untuk melindungi segenap masyarakat desa, termasuk dalam hal pertanian. Arwah leluhur ini biasanya disebut danyang desa, yakni makhluk halus yang menjadi pelindung desa.

\footnotetext{
46 William L. Reese, Dictionary of Philosophy and Religion (USA: Humanities Press, 1980), 28.

47 Abdul Qudus, "Echoteology Islam: Teologi Konstruktif Atasi Krisis Lingkungan”, Ulumuna: Jurnal Studi Keislaman, Vol. 16, No. 2 (Desember, 2012), 318.
} 
Dalam tradisi sedekah bumi masyarakat Made modern juga terkandung unsur kepercayaan terhadap Zat Yang Gaib. Sebagaimana penuturan Mbah Seniman, bahwa sedekah bumi masyarakat Made dilakukan dalam rangka bersyukur kepada Tuhan dan menghindarkan masyarakat Made dari bencana. ${ }^{48}$ Sesaji yang digunakan dalam sedekah bumi merupakan simbol permohonan keselamatan masyarakat kepada Tuhan Yang Maha Esa. ${ }^{49}$ Dalam penjelasan tersebut diketahui Zat Gaib yang percayai dapat menghindarkan masyarakat dari bencana dan melindungi masyarakat Made adalah Tuhan Yang Maha Esa.

Istilah Tuhan Yang Maha Esa adalah istilah umum yang digunakan di Indonesia, untuk mewakili istilah atau nama Tuhan dalam agama-agama yang berkembang di Indonesia. Setiap agama memiliki istilah atau penamaan tersendiri untuk Tuhannya, di Islam dikenal Allah, Kristen menyebutnya Allah, Hindhu menyebutnya Sang Hyang Widi Wase, Budhah menyebutnya Isware, Kebatinan atau Aliran Kepercayaan di Jawa menyebutnya Gusti Pengeran, Gusti Allah, dan sebagainya. Untuk mewadahi istilah-istilah tersebut digunakan istilah Tuhan Yang Maha Esa. Istilah tersebut juga merujuk pada dasar negara Indonesia, Sila Pertama Pancasila, yang berbunyi "Ketuhanan Yang Maha Esa."

Sila Ketuhanan Yang Maha Esa dalam Pancasila pada prinsipnya menegaskan bahwa bangsa Indonesia dan setiap warga negara harus mengakui adanya Tuhan. Oleh karena itu, setiap orang dapat menyembah Tuhan-nya sesuai keyakinannya masing-masing. Segenap rakyat Indonesia mengamalkan dan menjalankan agamanya dengan cara yang berkeadaban, yaitu hormat menghormati satu sama lain. Negara menjamin kemerdekaan tiap-tiap penduduk untuk memeluk agamanya masing-masing dan untuk beribadat menurut agamanya dan kepercayaannya. Negara Indonesia adalah satu negara yang berTuhan. Dengan demikian, segenap agama yang ada di Indonesia mendapat tempat dan perlakuan yang sama dari negara. Sila ini menekankan fundamen etis-religius dari negara Indonesia yang bersumber dari moral Ketuhanan yang diajarkan agama-agama dan keyakinan yang ada, sekaligus pengakuan akan adanya berbagai agama dan kepercayaan terhadap Tuhan Yang Maha Esa di Indonesia. ${ }^{50}$

\footnotetext{
48 Seniman, Wawancara, 20 Juni 2016.

49 http://www.surabaya.go.id, "Antusias Warga di Panen Raya Kelurahan Made”, Diakses 13 Juli 2016.

${ }^{50}$ MPR RI, Empat Pilar Kehidupan Berbangsa dan Bernegara (Jakarta: Sekretariat Jenderal MPR RI, 2012), 45-46.
} 
Secara substansi, Pancasila tidak bertentangan dengan pandangan teologi Islam. Islam mengakui adanya satu Tuhan, satu Zat yang patut disembah sebagai prinsip ketauhidan dalam Islam. Tauhid dalam Islam berarti memposisikan Allah sebagai Rabb dan Ilāh di tengahtengah alam dan manusia, tidak ada Rabb dan Iläb di tengah alam semesta ini melainkan hanya Dia. Konsep Tauhid inilah yang menjadi gagasan pokok dalam dakwah para rasul. ${ }^{51}$ Mohammad Natsir, salah seorang tokoh Islam di Indonesia, dengan tegas menyebutkan bahwa "Pancasila sesuai dengan Islam dan Islam tidak mungkin bertentangan dengan Pancasila." 52

Penggunaan istilah Ketuhanan Yang Maha Esa sebagai Zat yang dituju dalam tradisi sedekah bumi masyarakat Kelurahan Made menggambarkan bagaimana nilai-nilai dalam sila pertama Pancasila telah hidup dalam konteks masyarakat Kelurahan Made yang modern. Secara sosiologis masyarakat Made modern adalah masyarakat yang plural. Sekalipun Islam menjadi agama mayoritas, tetapi terdapat agama dan kepercayaan lain yang diakui dan dihormati. Sekalipun etnis Jawa adalah mayoritas, tetapi terdapat suku lain yang diakui dan dihormati dalam lingkungan masyarakat Kelurahan Made. Sesepuh adat masyarakat Made, yaitu Mbah Seniman adalah seorang yang beragama Hindhu dan beretnis Madura. ${ }^{53}$ Ia hidup berdampingan dengan tokoh-tokoh lain yang beragama Islam dan beretnis Jawa. Bahkan, ia selalu memimpin kegiatan sedekah bumi, di mana mayoritas pesertanya adalah Muslim Jawa.

Bagi masyarakat Muslim Made, rasa syukur dan doa permohonan keselamatan bagi masyarakat Kelurahan Made tetap ditujukan kepada Allah, bukan kepada yang selainnya. Sekalipun dalam masyarakat Muslim Made juga memiliki orientasi kultural yang beragam, namun simbol Ketuhanan yang dituju adalah sama yaitu Allah. Hal ini sebagaimana dinyatakan oleh salah seorang tokoh Muslim Kelurahan Made, Muhammad Nasyik Fahmi. Baginya, ritual sedekah bumi merupakan bagian dari budaya yang berkembang dalam masyarakat Kelurahan Made. Upacara itu diyakini tidak menyimpang dari ajaran Islam. Nasyik Fahmi menegaskan, "Upacara tersebut merupakan akulturasi kebudayaan dan agama. Yang menyatu hanya ritual doa

51 Iskandar Al-Warisyi, Dakwah Illabiayah: Jalan Dakwah Tujub Rasul Allah dalam Memperbaiki Masyarakat Jahiliyah (Surabaya: Al-kahfi Media Press, 2009), 118, 135.

52 Deliar Noor, Islam, Pancasila, dan Asas Tunggal (Jakarta: Yayasan Perkhidmatan, 1984), 110.

${ }^{53}$ Seniman, Wawancara, 20 Juni 2016. 
bersama dalam sedekah bumi. Secara fikih tetap tidak ada penyatuan, dan tujuan sedekah bumi adalah memohon keselamatan kepada Allah." ${ }^{54}$

Sementara bagi masyarakat Hindhu Kelurahan Made, rasa syukur dan doa agar masyarakat Made selamat terhindar dari bencana ditujukan kepada Sang Hyang Widi Wase. Demikian pula dalam penganut kepercayaan dan kelompok-kelompok yang masih mempercayai adanya kekuatan arwah leluhur, danyang desa, maka sahsah saja dalam ritual sedekah bumi tersebut rasa syukur dan permohonan keselamatan ditujukan kepada Gusti Pengeran, atau para arwah leluhur, dan danyang desa.

Artinya, rasa syukur dan doa tidak hanya ditujukan kepada Tuhan yang menjadi simbol satu agama atau kepercayaan saja, tetapi mencakup seluruh Tuhan yang dipercayai masyarakat Kelurahan Made yang beragam agama dan kepercayaannya, termasuk kepada arwah Mbah Singo Joyo yang dianggap sebagai danyang desa Made. Dalam konteks ini, masyarakat Kelurahan Made seperti mencampuradukkan pemahaman akidah antara Islam dan Hindu, atau antara Islam dan Aliran Kebatinan. Sungguhpun demikian, adanya kelompok-kelompok sinkretis tersebut, tetap diakui dan dihormati sebagai bagian dari ragam kepercayaan masyarakat Kelurahan Made.

Ini berarti, ragam agama dan kepercayaan dapat berkolaborasi sedemikian rupa dalam ritual sedekah bumi tanpa memasuki ranah akidah masing-masing. Konstruksi tersebut sejalan dengan realitas sosial masyarakat Made modern yang plural. Dalam konteks ritual sedekah bumi inilah, berbagai kelompok agama dan kepercayaan dalam masyarakat Made dapat bertemu dan berkumpul bersama, untuk kemudian memanjatkan rasa syukur dan doa bersama bagi keselamatan bersama.

\section{Dimensi Nilai-nilai Menghargai Bumi (Alam)}

Elemen kedua dalam dimensi teologi ritual sedekah bumi masyarakat Made modern adalah nilai-nilai untuk menghargai bumi (alam). Nilai-nilai tersebut dibangun atas dasar dua hal: a). kepercayaan terhadap Zat Yang Gaib dalam berbagai agama dan kepercayaan mengharuskan pemeluknya untuk memberikan perhatian dan penghargaan terhadap bumi (alam); dan b) perkembangan realitas

54 Syahrul, “Adakan Ritual”, Jawa Pos, 20 September 2007. 
kealaman yang terjadi di wilayah Made menunjukkan satu indikasi adanya sikap tak acuh dan ketidakpedulian terhadap alam.

Dalam ritual sedekah bumi masyarakat Kelurahan Made rasa syukur dan memohon keselamatan ditujukan kepada Tuhan Yang Maha Esa yang dipandang mewakili agama-agama dan kepercayaan dalam masyarakat Kelurahan Made. Tuhan Yang Maha Esa di antaranya dipandang sebagai Pencipta, Pemelihara, dan Pelindung. Dia-lah yang telah menciptakan alam dan menjadikan alam ini ada untuk manusia. Oleh karena itu, manusia harus mensyukuri segala pemberian alam, yang pada hakekatnya adalah pemberian Tuhan. Sebagai wujud rasa syukur itu pula, manusia memiliki kewajiban untuk menjaga alam (bumi).

Secara konseptual, membangun sebuah teologi yang berbasis kesadaran dan kearifan ekologi disebut sebagai ecotheology. Ecotheology adalah bentuk teologi konstruktif yang menjelaskan hubungan agama dan alam (interrelationships of religion and nature), khususnya dalam hal lingkungan. Dasar pemahaman ecotheology adalah kesadaran bahwa krisis lingkungan tidak semata-mata masalah yang bersifat sekuler, tetapi juga problem keagamaan yang akut karena berawal dari pemahaman agama yang keliru tentang kehidupan dan lingkungan. Melalui ecotheology, dilakukan tafsir ulang terhadap pemahamanpemahaman agama di tengah masyarakat, utamanya mengenai posisi manusia, relasi, dan tanggung jawabnya berkaitan dengan bumi ini. ${ }^{55}$

Dalam ajaran Islam, konsep ecotheology ditunjukkan di antaranya dalam beberapa narasi al-Qur'ān: a) tujuan penciptaan alam adalah untuk pemenuhan kebutuhan manusia (Q.S. al-Jāthiyah [45]: 13), sehingga dalam konteks ayat ini manusia diperintahkan untuk mengelola dan memanfaatkan alam dengan cara yang baik dan sesuai dengan aturan yang ditetapkan oleh Allah. Meski demikian, terkadang Q.S. al-Jāthiyah [45]: 13 inilah yang sering menjadi landasan teologis untuk melegitimasi pengeksplotasian alam oleh manusia; b) aturan pengelolaan dan pemanfaatan alam oleh manusia sebenarnya dibingkai dan dibatasi dengan perintah untuk tidak berbuat kerusakan, tidak serakah dan menyia-nyiakannya, tidak mengeksploitasi, tidak boros (Q.S. al-A'rāf [7]: 31 dan Q.S. al-Isrā' [17]: 27). Islam melarang pemanfaatan alam yang mengarah pada eksploitasi dan pengerusakan

55 Qudus, “Echoteology Islam”, 317. 
alam, spesies tumbuh-tumbuhan dan hewan serta mikroorganisme lainnya. ${ }^{56}$

Dalam ecotheology Islam, Tuhan menyatakan bahwa alam semesta beserta segala isinya adalah milik-Nya (Q.S. al-Baqarah [2]: 284). Manusia hanya berstatus pengelola dan pemelihara alam dalam kerangka pemenuhan tujuan yang telah direncanakan oleh Tuhan (Q.S. al-Ahqāf [46]: 3). Dari ayat di atas dapat dipahami bahwa alam ini bukanlah milik manusia. Kepemilikan manusia tersebut hanyalah bersifat amanah, titipan atau pinjaman yang pada saatnya nanti harus dikembalikan dengan pertanggungjawaban terhadap pemilik-Nya. Sebagai pengemban amanah seharusnya manusia tidak bertindak eksploitatif dan merusak alam yang akan menyebabkan manusia menerima murka Allah dan tergolong sebagai orang zalim, tidak boros dengan perilaku konsumtif terhadap sumber daya alam. ${ }^{57}$

Sementara dalam keyakinan Mbah Seniman, bumi (alam) bagi masyarakat Kelurahan Made adalah kehidupan. Artinya, tanpa adanya bumi masyarakat Kelurahan Made tidak bisa hidup. Oleh karenanya, bumi harus dijaga dan dihargai. ${ }^{58}$ Pandangan semacam itu juga terkait pada kepercayaan bahwa alam memiliki kekuatan atau hukum-hukum alam. Siapa yang merusak alam akan merasakan akibatnya atau yang diistilahkan dengan hukum karma. Bagi Mbah Seniman, jika manusia atau masyarakat Kelurahan Made menginginkan agar alam dapat terus memberikan manfaat atau mendatangkan kebaikan bagi masyarakat, maka mereka harus menghargai dan memelihara alam sekitarnya. Melalui ritual sedekah bumi, masyarakat Made modern diingatkan akan keadaan bumi atau alam sekitarnya, sehingga sedekah bumi menjadi simbol untuk menghargai bumi. ${ }^{59}$

Lebih jauh terkait perkembangan keadaan bumi (alam) di wilayah Kelurahan Made sekarang sudah berbeda dengan dahulu. Menurut Mbah Seniman, "sebelum tahun 1960an, seandainya diumpakan 100\% air hujan turun ke bumi, maka seperempatnya (25\%) kembali ke laut, dan tiga perempatnya $(75 \%)$ meresap ke dalam tanah karena sawahsawah masih ada, sehingga udara terasa sejuk. Kondisi sekarang sudah terbalik, $75 \%$ air hujan ke laut dan $25 \%$ meresap ke bawah tanah, sebab tanah sudah tertutup bangunan, aspal jalan, dan sebagainya.

\footnotetext{
${ }^{56}$ Ibid., 332-333.

57 Ibid., 340-342.

${ }^{58}$ Seniman, Wawancara, 20 Juni 2016.

${ }^{59}$ Ibid.
} 
Akhirnya yang terjadi adalah orang merasa kepanasan. Inilah akibat manusia tidak menghargai bumi/alam. Manusia bersifat kurang (selalu merasa kurang dan tidak pernah puas). Alam dirusak, sekarang akibatnya dapat dirasakan apabila musim panas, panasnya luar biasa, jika musim hujan dinginnya luar biasa. Manusia kini hidup bercampur besi-besi, batu-batu, buatan manusia sendiri (seperti gedung-gedung berkaca, bangunan-bangunan, dan lain-lain), dan lupa dengan bumi (tanah/alam)."

Memang, wilayah Kelurahan Made mulanya adalah daerah pinggiran Surabaya yang cukup terasing, didominasi lahan pertanian, dan jauh dari pusat kota. Dalam perkembangannya, ketika para pengembang perumahan masuk dan terdapat program perluasan kota Surabaya, sedikit demi sedikit wilayah Kelurahan Made, juga beberapa wilayah lain di Surabaya Barat, seperti Sambikerep, Lontar, Lakarsantri, dan sebagainya, berubah menjadi perumahan-perumahan elit, sarana hiburan, tempat-tempat pendidikan, perkantoran, toko, dan lain-lain. Hal ini yang dikhawatirkan oleh Mbah Seniman, selaku sesepuh Desa Made, yang menjadi saksi hidup akan perkembangan dan perubahan alam di Kelurahan Made. Kini kawasan Surabaya Barat telah berkembang pesat, Kelurahan Made bukan lagi desa yang terasing, tetapi telah menjadi kota.

Dalam hal ini, akhirnya menjadi relevan apabila konstruksi teologis dalam ritual sedekah bumi masyarakat Kelurahan Made memasukkan unsur echoteology. Nilai-nilai teologis dikonstruk agar sejalan dengan dinamika realitas persoalan yang dihadapi masyarakat Kelurahan Made, sehingga dalam konteks itulah ritual sedekah bumi masyarakat Made mengandung nilai-nilai echoteologis.

\section{Dimensi Nilai-nilai Hidup Rukun Berdampingan}

Agama Islam memiliki dasar teologis agar umatnya turut menjaga kerukunan, terlebih apabila hidup dalam masyarakat yang plural. Islam memandang perbedaan sebagai fitrah yang sudah menjadi ketetapan Tuhan yang harus diterima oleh seluruh umat manusia. Penerimaan tersebut selayaknya juga diapresiasi dengan kelapangan untuk mengikuti seluruh petunjuk dalam menerimanya. Berdasarkan hal ini

${ }^{60}$ Ibid. 
pula maka toleransi menjadi satu ajaran penting yang dibawa dalam setiap risalah keagamaan, tidak terkecuali pada sistem teologi Islam. ${ }^{61}$

Sejumlah ayat al-Qur'ān dapat dijadikan landasan dalam bertoleransi, antara Q.S. Āl 'Imrān [3]: 19, Q.S. Yūnus [10]: 99, Q.S. al-Nahl [16]: 125, al-Kahfi [18]: 29, dan al-Mumtahanah [60]: 8-9. Poin paling penting dalam memahami tentang keharusan bertoleransi dalam kehidupan beragama ini adalah mengikuti sikap dan perilaku yang sudah dicontohkan oleh Nabi Muhammad semasa hidupnya, sebagaimana sikap yang ditunjukkan olehnya waktu Fath Makkah yang dilakukan umat Islam di bulan Ramadan. Di saat umat Islam mengalami euforia atas keberhasilannya membebaskan Mekah, sekelompok kecil sahabat Nabi yang berpawai memekikkan slogan alyawm yawm al-malhamah. Slogan ini dimaksudkan sebagai upaya balas dendam atas kekejaman orang musyrik Mekah kepada umat Islam sebelumnya. Gejala tidak sehat ini dengan cepat diantisipasi oleh Nabi Muhammad dengan melarang meneriakkan slogan tersebut dan menggantinya dengan slogan al-yawm yawm al-marhamah, sehingga pembebasan Mekah dapat terwujud tanpa harus terjadi insiden berdarah. $^{62}$

Toleransi dalam hidup beragama yang diajarkan Islam pada pemeluknya jika diterapkan secara seimbang akan melahirkan wajah Islam yang inklusif, terbuka, ramah, dan selaras dengan misi nubuwah: Isläm rahmat li al-álamin. Islam yang toleran ini dalam kelanjutannya merupakan pengejawantahan nilai-nilai universal Islam sebagai agama untuk seluruh manusia. Toleransi yang diajarkan oleh Islam tidak akan merusak misi suci akidah, melainkan lebih sebagai penegasan akan kepribadian Muslim di tengah pluralitas kehidupan beragama. Dengan demikian, satu sisi Islam dapat dikatakan lebih menghargai pribadi yang mampu bertanggungjawab secara sosial tanpa harus meninggalkan nilai-nilai primordialnya sebagai Muslim. Jika inti dari ajaran beragama adalah tidak menyekutukan Allah, berbuat baik, dan beriman pada hari akhir, maka sikap toleran adalah satu misi yang terkandung dalam poin berbuat kebajikan tersebut. ${ }^{63}$

61 Adeng Muchtar Ghazali, "Teologi Kerukunan Beragama dalam Islam: Studi Kasus Kerukunan Beragama di Indonesia", Jurnal Analisis, Vol. 13, No. 2 (Desember 2013), 284.

62 Ibid., 285

63 Ibid. 286. 
Dalam konteks ritual sedekah bumi, Mbah Seniman telah munuturkan bahwa inti sedekah bumi tidak hanya untuk menghindarkan masyarakat Kelurahan Made dari bencana, tetapi sekaligus sebagai bentuk persaudaraan antarwarga. ${ }^{64} \mathrm{Hal}$ tersebut tercermin dalam tata cara pelaksanaan upacara sedekah bumi. Pertama, dalam penentuan waktu yang didasarkan atas kesepakatan bersama antarwarga Kelurahan Made, termasuk elemen dari pemerintah, tokoh agama, dan perwakilan keluarga. Warga wajib berkumpul di Balai Kelurahan. ${ }^{65}$ Kedua, dalam penyiapan tumpeng yang digunakan dalam sedekah bumi. Dalam hal ini warga Kelurahan Made juga bekerjasama, bahu membahu untuk menyiapkannya. Ketiga, terdapat kegiatan-kegiatan kesenian yang melibatkan partisipasi banyak warga, seperti okol yang sudah menjadi tradisi khas masyarakat Kelurahan Made. ${ }^{66}$ Keempat, nilai-nilai kerukunan juga digambarkan dalam simbol potong pithik sebagai salah satu sesaji yang disiapkan dengan tumpeng. ${ }^{67}$ Filosofi simbol potong pithik menggambarkan agar melalui sedekah bumi, masyarakat Kelurahan Made menyadari dan membuang sifatsifat buruknya sebagaimana ayam yang selalu bertarung apabila dikumpulkan, sehingga harapannya masyarakat Seniman Made bisa hidup rukun dan berdampingan. Sekalipun berbeda agama, berbeda etnis, harus bisa rukun dan toleransi antar-agama. Kelima, secara sosiologis masyarakat Kelurahan Made adalah masyarakat yang plural, sehingga konsep teologi kerukunan yang dikonstruk melalui ritual sedekah bumi sejalan dengan situasi sosial yang melingkupinya.

\section{Penutup}

Secara umum terdapat tiga tujuan dalam ritual sedekah bumi masyarakat Kelurahan Made saat ini, yaitu memohon keselamatan kepada Tuhan Yang Maha Esa dan arwah Mbah Singojoyo selaku pelindung masyarakat kelurahan Made agar terhindar dari bencana, mengingatkan masyarakat secara umum dan masyarakat Made khususnya untuk menghargai alam sebagai sumber kehidupan, dan sebagai sarana untuk membangun persaudaraan dan kerukunan antarwarga Kelurahan Made.

\footnotetext{
${ }^{64}$ Seniman, Wawancara, 20 Juni 2016.

65 http:/ / desomade.blogspot.co.id, "Histori Made”, Diakses 20 Juni 2016.

66 "Adu Okol di Sedekah Bumi”, Jawa Pos, 31 Oktober 2016.

${ }^{67}$ Ibid.
} 
Berpijak pada tujuan dan tata cara pelaksanaan ritual sedekah bumi masyarakat Made tersebut, maka dimensi-dimensi teologi dalam ritual sedekah bumi masyarakat Made modern dapat diidentifikasi sebagai kepercayaan terhadap Zat Yang Gaib, nilai-nilai untuk penghargaaan terhadap alam (echoteology), dan nilai-nilai untuk hidup rukun berdampingan antar-warga masyarakat Kelurahan Made yang plural tanpa membedakan suku, agama, ras, dan golongan. Dimensidimensi teologis dalam ritual sedekah bumi ini telah dikembangkan sedemikian rupa agar sejalan dengan perkembangan realitas sosial dan kealaman yang melingkupi. Hal ini menunjukkan bahwa agama atau kepercayaan tidak semata terkait persoalan normatif dan doktriner tetapi juga dapat berdialektika, melakukan akomodasi maupun kolaborasi, dengan realitas yang melingkupinya, sehngga teologi memiliki nilai praksis yang dapat dirsasakan langsung oleh masyarakat.

\section{Daftar Rujukan}

\section{Buku dan Jurnal}

Al-Warisyi, Iskandar. Dakwah Illabiayah: Jalan Dakwah Tujuh Rasul Allah dalam Memperbaiki Masyarakat Jahiliyah. Surabaya: Al-kahfi Media Press, 2009.

BPS Kota Surabaya, Kecamatan Sambikerep, 54.

Geertz, Clifford. Agama Jawa: Abangan, Santri, Priyayi dalam Kebudayaan Jawa, terj. Aswab Mahasin. Jakarta: Pustaka Jaya, 1985.

Ghazali, Adeng Muchtar. "Teologi Kerukunan Beragama dalam

Islam: Studi Kasus Kerukunan Beragama di Indonesia”, Jurnal Analisis, Vol. 13, No. 2, Desember 2013.

Kuntowijoyo. Esai-esai Budaya dan Politik: Selamat Tinggal Mitos Selamat Datang Realitas. Bandung: Mizan, 2002.

MPR RI, Empat Pilar Kehidupan Berbangsa dan Bernegara. Jakarta: Sekretariat Jenderal MPR RI, 2012.

Mulder, Niels. Kepribadian Jawa dan Pembangunan Nasional. Yogyakarta: Gadjah Mada University Press, 1981.

Noor, Deliar. Islam, Pancasila, dan Asas Tunggal. Jakarta: Yayasan Perkhidmatan, 1984.

Nurwicaksono, Bayu Dwi. "Eksplorasi Nilai Budaya dan Pendidikan Karakter Berbasis Kearifan Lokal dalam Tradisi Lisan Rupa Bumi dan Ancangan Revitalisasinya Melalui Implementasi Kurikulum 2013 dan Program Agrowisata”. Tesis--Universitas Pendidikan Indonesia, 2013. 
Qudus, Abdul. "Echoteology Islam: Teologi Konstruktif Atasi Krisis Lingkungan", Ulumuna: Jurnal Studi Keislaman, Vol. 16, No. 2, Desember, 2012.

Reese, William L. Dictionary of Philosophy and Religion. USA: Humanities Press, 1980.

Said, Nur. “Teologi Islam Kontekstual-Transformatif”, Jurnal Fikerah, Vol. 1, No. 1, Januari-Juni, 2013.

Slamet DS., Upacara Tradisional dalam Kaitan Peristiwa Kepercayaan. t.t.: Depdikbud, 1984.

Surabaya, BPS Kota. Kecamatan Sambikerep dalam Angka tahun 2016. Surabaya: BPS Kota Surabaya, 2016.

Widodo, Dukut Imam. Hikajat Soerabaia Tempo Doeloe, Vol. 2. Surabaya: Dukut Publishing, 2008.

\section{Wawancara}

Seniman. Wawancara. 20 Juni 2016.

\section{Media Online}

“Adu Okol di Sedekah Bumi”, Jawa Pos, 31 Oktober 2016.

http://desomade.blogspot.co.id, "Histori Made", Diakses 20 Juni 2016.

http://www.surabaya.go.id, "Antusias Warga di Panen Raya Kelurahan Made”, Diakses 13 Maret 2016.

Syahrul, Dedy H. "Kelurahan Made, Kampung Bali di Surabaya Adakan Ritual Bersama, Rukun meski Beda Agama", Jawa Pos, 20 September 2007.

Syahrul, “Adakan Ritual”, Jawa Pos, 20 September 2007.

Syahrul, "Kelurahan Made", Jawa Pos, 20 September 2007.

http://ayokesurabaya.com, "Kampung Made Balinya Surabaya", Diakses 8 Juni 2016; Dokumen Mbah Seniman, "Sejarah Singkat Desa Made Mengenai Tokoh Pejuang 45 dan Bangunan Punden". 